\title{
A temporal dimension of household vulnerability in three rural communities in Lijiang,
} China

Zheng, Yuan; Byg, Anja; Thorsen, Bo Jellesmark; Strange, Niels

Published in:

Human Ecology: An Interdisciplinary Journal

DOI:

$10.1007 / \mathrm{s} 10745-013-9633-5$

Publication date:

2014

Document version

Early version, also known as pre-print

Citation for published version (APA):

Zheng, Y., Byg, A., Thorsen, B. J., \& Strange, N. (2014). A temporal dimension of household vulnerability in three rural communities in Lijiang, China. Human Ecology: An Interdisciplinary Journal, 42(2), 283-295.

https://doi.org/10.1007/s10745-013-9633-5 
Pre-print. This is an earlier version of the paper published as and to be cited as:

Zheng, Y., A. Byg, B.J. Thorsen and N. Strange, 2014: A Temporal Dimension of Household Vulnerability in Three Rural Communities in Lijiang, China. Human Ecology, 42, 283-295. See http://link.springer.com/article/10.1007/s10745-013-9633-5 
Farmers' livelihood dynamics around Yulongxueshan: A temporal dimension of vulnerability of rural communities in Lijiang, China

\begin{abstract}
In this paper, the dynamics of households' vulnerability during the past 30 years is depicted within three different social-ecological upland systems in Lijiang, Yunnan. Interviews were conducted to construct coupled human-environmental timelines to facilitate the understanding of livelihood dynamics seen in the context of more general changes which constitute both constraints and opportunities.
\end{abstract}

The results indicate that significant livelihood changes include specialization, diversification and migration, which have been primarily driven by socio-political influences. Overall vulnerability of households has decreased differently across villages. Nevertheless, climate change is a concern as households perceive increasing temperature, declining precipitation and unpredictable extreme events. In the future, households' vulnerability might increase since important components of current livelihoods remain climate sensitive. Moreover, environmentally destructive practices such as illegal logging might reinforce the negative impacts of climate change and thus undermine sustainable adaptation.

Key words: diversification, climate change, adaptation, Yunnan 


\section{Introduction}

In China, the past 30 years have been characterized by significant adjustments in the socio-political system such as increasing market liberalization and privatization as well as by environmental problems and natural disasters (e.g., droughts, floods, dust storms, several large earthquakes). Economic development is expected to continue while climate change is likely to cause further environmental problems. The ways in which people have adapted to both socio-economic and environmental changes in the past have important implications for their present and future adaptive capacity and vulnerability. In this study we investigated rural households' past responses to opportunities and challenges in three communities in Lijiang, Yunnan province, southwestern China, as well as their concerns related to the future. The three communities are located at different elevations and hence vary in terms of environmental conditions as well as access to infrastructure, goods and services.

Both previous studies and as well as more theoretical works have emphasized the role of livelihood diversification as a means of adaptation and economic development for rural households (e.g., Ellis 1998; Ellis 2000a; Ellis 2000b; Ellis and Allison 2004). However, diversification may not always be the preferred or most lucrative option for households (e.g., Coulthard 2008). Instead, specialization may at times be an economically more attractive option due to higher returns to labor (e.g., Eriksen et al. 2005; Liu et al. 2008). However, specialization may require resources such as access to education, irrigation or transport which may not be available to all households (e.g., Eriksen et al. 2005; McDowell and Hess 2012). The attractiveness of different strategies may change over time as market conditions, available technologies, household composition and aspirations change (e.g., Hageback et al. 2005; Liu et al. 2008). In addition, lucrative strategies may not always be sustainable and may hence contribute to increased vulnerability in the future. 
The paper aims to contribute to the burgeoning body of research on temporal dimensions of vulnerability. Specifically, the paper attempts to answer the following questions:

1. How have rural households' livelihoods changed over time?

2. What factors have driven such livelihood changes and what role has climate change played?

3. What are the implications of these livelihood changes for the communities' vulnerability?

\section{Theoretical background}

The concept of vulnerability

A prevailing definition within the climate change literature characterizes vulnerability as a function of exposure, sensitivity and adaptive capacity (Adger 2006; Smit and Wandel 2006). The term 'exposure' refers here to the likelihood of experiencing particular hazards, 'sensitivity' to the degree of susceptibility to harm from a hazard, and 'adaptive capacity' to the capacity 'to adjust to climate change (including climate variability and extremes), to moderate potential damages, to take advantage of opportunities, or to cope with the consequences' (IPCC 2001). This has directed attention to vulnerability embedded within the coupled human-environment system, highlighting the varied linkages, iterative processes and potential dynamics that comprise vulnerability at nested scales and its development over time (Turner et al. 2003).

The livelihood approach

To investigate issues of vulnerability and households' responses to changes, the study employs a sustainable livelihood approach (Scoones 1998), which emphasizes the capabilities of households to deploy an ensemble of assets to carry out a combination of viable livelihood activities (Ellis and Biggs 2001). The ability to implement such strategies depends on the established context which regulates access to specific resources. The context consists of both exogenous factors 
(predominantly trends and shocks in biophysical and socio-economic domains) and endogenous factors (mainly institutions and organizations that govern internal social norms and structures which regulate the access to resources) (Ellis 2000b). This framework has provided useful insights into the links between dynamics of social and environmental changes, and decision-making at the local level (Eakin and Luers 2006; Porro 2005).

The livelihood approach can be used to look at the way households respond to climatic and other stressors by adopting different livelihood strategies (Scoones 1998). In this context, adaptation is seen as a process through which households continuously strive for wealth accumulation or poverty reduction by inducing changes (Davies and Hossain 1997; Ellis 1998). Adaptation is often differentiated from coping, with the latter term referring to short-term responses that aim to mitigate impacts of negative events. In this restricted sense, adaptation is used to refer to longer term alterations of livelihood strategies with the aim of reducing future exposure, sensitivity or impacts (Scoones 1998). However, livelihood changes may also be undertaken to take advantage of new options such as investing (time, effort, capital) in new technology to enhance income. These are of importance for rural households to enhance their capacity to avoid poverty traps and to develop (Dercon 2002; Malchow-Møller and Thorsen 2005).

The contribution of a temporal dimension Analysing past and present livelihood responses to climatic as well as non-climatic changes can generate insights for future planning (Paavola 2008; Reenberg 2011). Dearing et al. (2010) stressed the need to employ a long time perspective in order to detect slow-moving processes (e.g., environmental and cultural trends) and second-order changes (e.g., perception of risk and challenges) that are pivotal to stability. Moreover, without such a focus analyses may be biased 
toward the recent past (Dearing et al. 2010). Embedding the analysis within its historical context helps to identify future transformation needs by focusing on those points in time that engendered most responses and highlighting those elements that in isolation or combination determined what alternatives were available to households (Paavola 2008; Reenberg 2011).

The analysis of 'livelihood trajectories' can be used to gain insights into the patterns and changes of livelihood activities in the communities (Bagchi et al. 1998). The analysis links people's life stories to the broader context constituting opportunities or constraints to their functioning and adaptive capacities (Bagchi et al. 1998; De Haan and Zoomers 2005). Therefore, a livelihood trajectory approach allows for a deeper understanding of needs, aspirations, and restraints of people's lives, which are anchored in 'historical repertoire and social differentiation' (De Haan and Zoomers 2005). The trajectories of change may be best understood by exploring the co-evolvement of multiple forces and corresponding livelihood strategies, which can be accomplished by a simple heuristic device called 'coupled human-environmental timelines' (Nielsen and Reenberg 2010; Reenberg et al. 2008).

The study presented here attempts to investigate vulnerability that varies in space and time while acknowledging the influences of processes at broader scales upon resource management at local level. We use the obtained insights to cast light on the adaptation lessons learnt from local experiences of three spatially distinctive social-ecological systems in a historical process.

\section{The study site}

The study was carried out in three villages in three different townships in Yulong Naxi Autonomous County, Lijiang, northwestern Yunnan Province, People's Republic of China (Fig. 1). All three 
villages are located in the vicinity of the Jade Dragon Snow Mountain (named 'Yulongxueshan' in Chinese). This site has become a famous tourist attraction since the late 1990s due to its scenic qualities (forests and snow covered mountains), high levels of biodiversity and ethnic diversity. For instance, the number of tourists visiting the mountain rose from 63.9 thousand to 1.76 million between 1995 and 2004 (Yuan et al. 2006). It also harbours China's southernmost temperate glacier which is seen as an archetypical indicator of global warming due to its rapid retreat during the $20^{\text {th }}$ century (Ning et al. 2006).
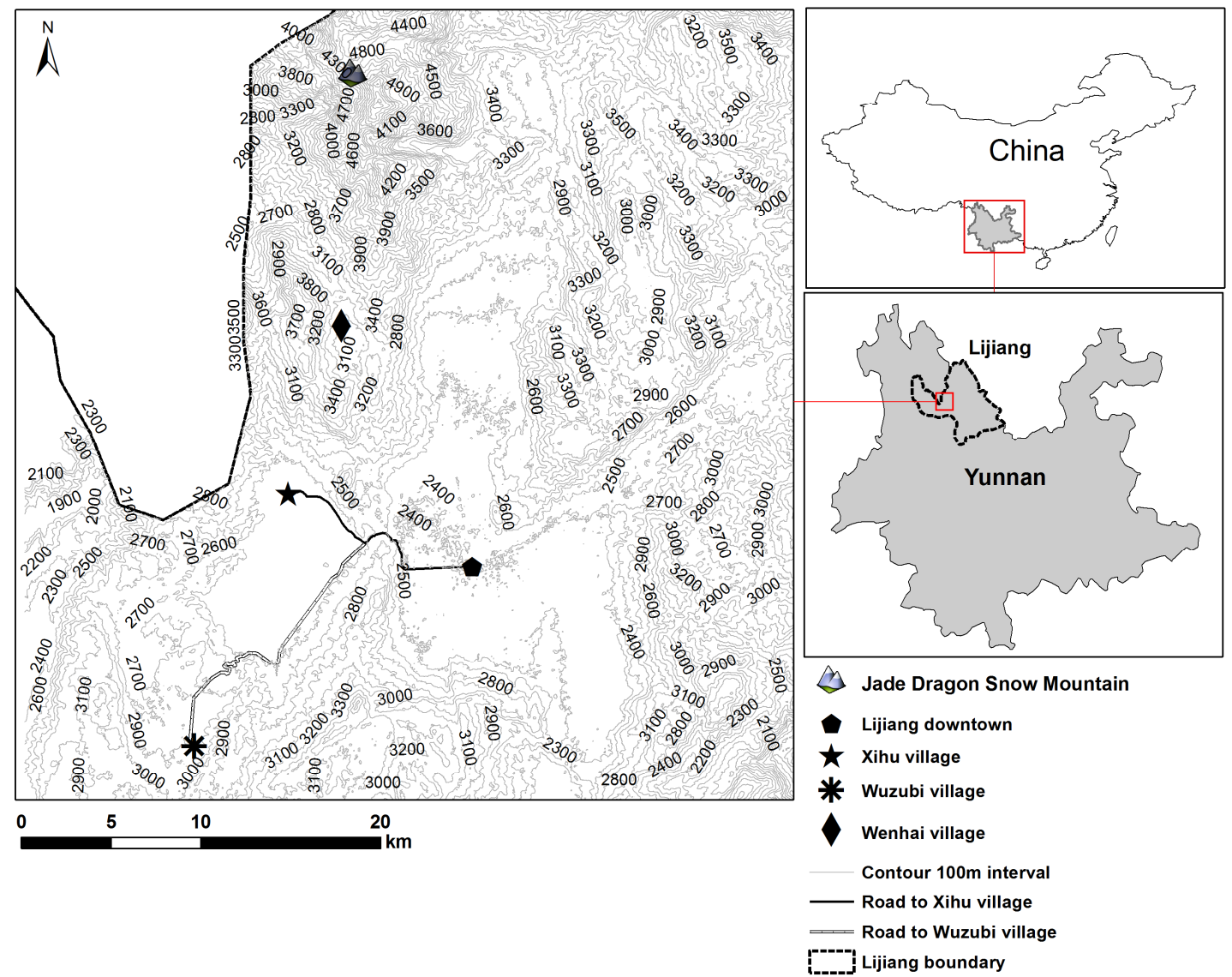

Fig. 1 Sites of study villages in Lijiang, Yunnan province, China. Source: Environmental Systems Research Institute (ESRI) country dataset

At the lowest elevation is Xihu village belonging to Lashi Township and inhabited by the Naxi ethnic group (Table 1). The climate is relatively warm and dry and farmers have specialized in fruit tree plantations, e.g., the well-known fruit 'Lijiang snow peach'. With the relatively long growth 
season (around 200 days), the fruit is highly productive (producing as much as $0.75 \mathrm{~kg} / \mathrm{m}^{2}$ ) and profitable (trading at $4.89 \mathrm{US} \$ / \mathrm{kg}$ at the time of the study). The location of Xihu village close to Lashi Lake has promoted the development of tourism in recent years, including horse-riding, fishing and small business such as running restaurants, which are now making important contributions to many farmers' livelihoods.

At the intermediate elevation lies Wuzubi, which is a Naxi village belonging to Taian Township. It is characterised by a cooler climate and large-scale potato and rapeseed production which are the dominant livelihood activities in the area. Wenhai administrative village is located at the highest elevation and belongs to Baisha Township. In contrast to the other two villages, residents in Wenhai belong to two different ethnic groups: Yi (Xuehua village) and Naxi (upper and lower villages of Wenhai). The climate is cold and moist, and farmers primarily grow crops such as potatoes, barley, buckwheat and turnips. Most of the agricultural production in Wenhai is for subsistence (Zackey 2007). Animal husbandry is an important livelihood element in addition to crop cultivation. Most households possess pigs, some also have horses and mules mainly for transportation, while a smaller number possess cattle and yak (Zackey 2007). The village is clustered around the northern shore of Wenhai Lake and tourism has recently begun to contribute to the livelihoods of a few of the residents (Sicroff et al. 2003). During agriculture and tourism downtimes, a significant number of households engage in charcoal making in order to earn cash (Zackey 2007). Villagers are also dependent upon fuel wood and charcoal for cooking and heating. In all three villages, collection of non-timber forest products (NTFP) (e.g., medicinal plants and mushrooms) is a supplemental and seasonal livelihood activity. 
Table 1 Characteristics of the villages around Jade Dragon Snow Mountain in Lijiang, northwest Yunnan visited during the study.

\begin{tabular}{|c|c|c|c|}
\hline Village & Xihu & Wuzubi & Wenhai \\
\hline No. of households & 72 & 100 & $176^{\mathrm{a} .}$ \\
\hline $\begin{array}{l}\text { No of households } \\
\text { interviewed }\end{array}$ & 8 & 11 & 21 \\
\hline Ethnic composition & Naxi nationality & Naxi nationality & $\begin{array}{l}\text { Naxi and Yi } \\
\text { nationality }\end{array}$ \\
\hline Elevation (m) & 2420 & 2790 & 3200 \\
\hline Climate & Warm & Cool & Cold \\
\hline Water source & Lashi Lake & No river/lake present & $\begin{array}{l}\text { Wenhai lake; ponds } \\
\text { available }\end{array}$ \\
\hline Transportation & $\begin{array}{l}\text { Paved road; } 30 \text { minute } \\
\text { drive to town }\end{array}$ & $\begin{array}{l}\text { Paved road; close to } \\
\text { Lijiang Astronomical } \\
\text { Observatory; } 40 \\
\text { minute drive to town }\end{array}$ & $\begin{array}{l}\text { Dirt road; } 90 \text { minute } \\
\text { drive to town }\end{array}$ \\
\hline Market access & Fairly easy & Very easy & Not easy \\
\hline Electricity & Yes & Yes & Yes \\
\hline $\begin{array}{l}\text { Extension service on } \\
\text { farming practice }\end{array}$ & Yes & Yes & No \\
\hline $\begin{array}{l}\text { Availability of } \\
\text { technology }\end{array}$ & Yes & Yes & No \\
\hline Access to irrigation & Yes & No & No \\
\hline $\begin{array}{l}\text { Primary livelihood } \\
\text { activities }\end{array}$ & $\begin{array}{l}\text { Subsistence farming, } \\
\text { fruit tree plantation } \\
\text { and tourism }\end{array}$ & $\begin{array}{l}\text { Commercial farming } \\
\text { of potatoes and } \\
\text { rapeseed }\end{array}$ & $\begin{array}{l}\text { Pastoralism, } \\
\text { subsistence farming, } \\
\text { charcoal making and } \\
\text { tourism }\end{array}$ \\
\hline
\end{tabular}

a. Wenhai administrative village contains eight village groups and in total there are 238 registered households. This study only involves Xuehua, Upper and Lower Wenhai village group. The statistics was recorded from chiefs of village groups.

\section{Methods}

Data was collected during September and October 2011 by means of structured household interviews, focus groups and secondary documents. A total of 40 individual household interviews were conducted using an interview guide. The households were selected according to their current socio-economic status (e.g., household composition, main income sources, assets) to cover the major types of households within each community. Normally, the household head was interviewed, but other members of the family also took part if they were present. Each interview started with questions regarding current characteristics of the household (e.g., family size, field size, current 
livelihoods, asset holdings). This was followed by questions about experiences of changes in their household during the past 30 years. Finally we asked about perceptions of causes and impacts of such changes upon livelihoods, the natural environment and socio-cultural aspects of life. Current concerns of households were also elicited to reveal the main area of focus in life. Climate change was not mentioned at this stage unless raised by interviewees themselves to avoid biasing their answers. Only later on were interviewees asked about their perceptions of, and concerns about, climate change (including general trends and extreme weather events) and their evaluations of its impacts. This was followed by further questions about coping and adaptive strategies to climatic variability.

In each community one focus group was organized with 5-6 participants in their 50s and 60s including both men and women. In the focus groups, people were asked to recall biophysical, socioeconomic and cultural changes and their impacts on livelihood conditions (Nielsen and Reenberg 2010). Secondary documents including newspaper articles, blogs, non-governmental organization (NGO) and government reports as well as journal papers were reviewed prior to the focus groups to gather background information on the historical context. Chains of events were constructed out of the participants' narratives to establish a coupled human-environmental timeline for each village covering the past 30 years.

Data were collected by two trained local assistants. Interviews were conducted in the Naxi dialect and took place at the interviewees' homes. All interviews were digitally recorded and transcribed into Mandarin Chinese with the help of local assistants. The transcripts were coded to identify the principal themes that emerged out of the responses. 


\section{Results}

The study covers the last 30 years beginning around the time when the 'Open-door policy' took effect in China (1978), followed by the 'Household Responsibility System (HRS)' (1981), which permitted farmers a greater degree of freedom in selecting and cultivating crops and gave them the right to sell agricultural produce (Hershkovitz 1993; Tilt 2008). In addition, the HRS made it possible for people in rural locations (i.e., people without urban registration status) to buy food and to decide themselves how to allocate their time (Zhao 1999). This had profound consequences as it enabled rural households to choose their own livelihood and to migrate to participate in the emerging labor market following the economic liberalization.

\section{Livelihood changes}

Subsistence farming dominated livelihoods of Xihu villagers in the first years following the 'Opendoor policy' and HRS (Fig. 2). Extra household labor was mainly employed in limited cash cropping and supplementary fishing in Lashi Lake. In 1996 an earthquake measuring 7.0 on the Richter scale shook the Lijiang area. Although it had devastating impacts on Xihu village, it was also deemed a turning point for the village. Following the earthquake large investments not only helped rebuild the village, but also provided infrastructure previously not accessible such as electricity and a road. This increased villagers' mobility and later enabled tourism development. Donations were used to establish two elementary schools and one clinic. The earthquake had a similar effect on the nearby town of Lijiang which was rebuilt entirely and redeveloped with regard to tourism attracting visitors to the larger area, including Xihu village.

Another significant change was the water transportation project from Lashi Lake to Lijiang in 1994. Together with over-fishing this brought an end to fishing activities in the lake as the project 
interfered with the natural water level fluctuations necessary for the regeneration of fish stocks. In addition, the project had far-reaching consequences for agriculture as farmland around the lake was flooded. The amount of available farmland decreased further as a result of the ensuing Lashi Lake conservation policy introduced in 1995, which required farmland close to the lake to be turned into protected wetland. In response to inadequate compensation for the flooded farmland, villagers started farming around $80,000 \mathrm{~m}^{2}$ on sloping land. However, these areas were heavily affected by landslides, mudflows and flooding associated with vegetation damage. As a result, villagers started to pursue alternative livelihoods. Seasonal migration was adopted at the time as another option. Villagers started to seek temporary jobs in Lijiang city and nearby towns (i.e., Diqing, Shangri-La etc.) and worked mainly in construction and tertiary service sectors.

External assistance (in addition to that triggered by the earthquake) acted as another prominent driver of livelihood changes and helped to counter the deteriorating agricultural situation. In 2000, a local NGO ('Greenwatershed') introduced fruit tree plantations on sloping land and provided subsidies for pear and peach seedlings, which led to substantial income increases. At the same time a former resident invested in the establishment of the first horse-riding team to develop a tourism business. As a consequence of these developments, Xihu villagers nowadays increasingly engage in non-farm activities, such as tourism, together with commercial fruit tree production. Small-scale agriculture with conventional vegetables and crops is still practiced for subsistence purposes. In 2000 , the provincial government helped to provide irrigation for the village which relieved pressure exerted by drought events to a great extent.

[Please insert Fig. 2 here] 
Following the introduction of the 'Open-door policy' and HRS, Wuzubi villagers focused primarily on private subsistence farming of crops such as corn, barley, oats and potatoes (Fig. 3). However, returns remained fairly low. During the 1980s and early 1990s extensive timber logging took place in the area. Villagers benefited from the massive deforestation as they could sell high-quality timber and obtain wooden building materials for their own houses for free. Wuzubi village was connected to electricity and road networks in the early 1980s, considerably earlier than the other two villages. The road access later became a decisive factor in promoting cash crop production by providing easy market access.

In Wuzubi village, government extension service and the villagers themselves played a significant role in triggering livelihood changes. Since 2000 Wuzubi villagers embarked on specialized largescale potato and rapeseed cultivation. This constituted a major shift from the previous situation when households depended on an assortment of crops. The degree of crop diversity decreased considerably after the conversion although some other crops were still cultivated. The change was due to a combination of villagers' own initiatives inspired by the example of adjacent villages and to the activities of an agricultural science station which had developed and distributed high-quality potatoes for planting in nearby villages. This agricultural specialization brought huge economic benefits. Consequently, a logging ban introduced in 1998 covering the entire upper reaches of the Yangtze and Yellow Rivers under the Natural Forest Protection Program (NFPP) did not adversely influence farmers' lives significantly. From 2006 onwards, a governmental drinking water project has provided easy access to clean drinking water for both people and the animals. This has spared villagers much effort fetching water from the mountains and collecting rain water from their roofs, enabling them to spend more time on other activities.

[Please insert Fig. 3 here] 
Following the 'Open-door policy' and HRS, Wenhai village also witnessed varied developments, though at a slower pace than the other two villages due to its remoteness and higher elevation (Fig. 4). Traditional livelihood activities comprised livestock rearing with summer transhumance to grazing areas in alpine meadows, and subsistence farming. Like Wuzubi village, logging was an important activity during the 1980s and 1990s and charcoal making became an important source of income. However, a community-based eco-tourism development project was launched in 1993 and 1994 as part of a cooperation between a Chinese and an American university. The aim was to substitute environmentally harmful activities (such as logging and charcoal making) with tourism as an alternative source of income. Consequently, a trekking route for independent backpackers was proposed around Jade Dragon Snow Mountain. Further, Wenhai Ecolodge was established and organized as a local cooperative of 56 households from upper Wenhai village, which later gained support from the US-based NGO 'Nature Conservancy'. In the meanwhile, a horse-riding business was developed with investments from the village chief of lower Wenhai village. Nevertheless, as tourism is a seasonal activity, villagers have tended to continue charcoal making outside of the tourism season to supplement their incomes.

More recently, significant drivers of changes included road construction supported by the government and, to some extent, the availability of electricity (from 1998). Although only dirt roads were made available (in 1998 for upper and lower Wenhai and in 2005 for the part called Xuehua), this has immensely improved villagers' access to town. Now they are able to use small vans for transport compared to previously when they needed to carry everything themselves or use horses. This has made it easier to buy food from markets in town and purchase construction materials. The advent of electricity facilitated information flow to Wenhai through television and radio broadcasts. 
Unlike Wuzubi village, Wenhai village was severely affected by the series of forest conservation policies implemented between 1998 and 2000; first the logging ban followed by the Sloping Land Conversion Program (SLCP), prohibiting cultivation on all slopes over $25^{\circ}$. The latter meant that the availability of farmland decreased markedly and the importance of agriculture declined in relative terms. To begin with, compensation provided under the SLCP served as a crucial income source for local people in the form of food provision and cash. However, as compensation decreased over time and the planting of a medicinal shrub (Prinsepia utilis Royle) which was meant to provide a new income source to villagers proved unsuccessful due to lack of water, grazing problems and the stop of planting subsidies, villagers gradually derived less benefit from the program. To compensate, people started increasingly participating in seasonal migration work as was the case in Xihu village.

The latest development (2010) was initiated by a private company, which leased $667,000 \mathrm{~m}^{2}$ farmland from the village to cultivate 'Maca' (Lepidium meyenii Walp). Free seedlings have been provided to the villagers and the plants are expected to be purchased by the company. So far, only a few households have engaged in trial planting and it is presumed that they will start receiving revenues from 2012.

[Please insert Fig. 4 here]

\section{General concerns}

In all three villages there was a shift in the main concerns in villagers' lives over the past 30 years.

Previously, the area was characterised by extreme poverty and main worries were food and clothing. By contrast, people are nowadays more affluent, which makes room for other concerns. Several common themes emerged from the responses. 
First and foremost, concerns about children always ranked on top of the list, including their education and future. Families generally hoped that the next generation could live a better life. Health and family unity were also important concerns. In addition, villagers paid a lot of attention to economic trends such as recent inflation, which impacted directly upon agricultural product prices and the cost of living. Government policies also received a lot of attention. Supportive policies such as medical insurance and pensions were already in place, and some hoped that there would be more such interventions to ameliorate welfare. Nevertheless, complaints about the government were common among villagers regarding lack of transparency and commitment and lack of village influence during decision-making. Last but not least, villagers talked consistently about the vanishing natural resources (e.g., forests, mushrooms, medicinal plants) as another source of worry. Climate change issues were seldom mentioned by villagers unless prompted for (see below).

However, there were also differences among villages. Villagers in Xihu began to doubt the profitability of current tourism business as increasing competition has caused a decline in prices for tourism services. Now villagers merely earn 20-30 Yuan (3-5 US\$) for a horse-ride lasting four to five hours. This was coupled with high risks as accidents may cause injuries to horses and tourists. Thus, while tourism was initially seen as an attractive alternative income source, villagers have become more skeptical.

In Wuzubi the predominant cause of concern was the current trend of the younger generation to migrate to the cities as this created uncertainty regarding who would continue farming in the future. The practical consequences were seen as being partly off-set by existing welfare policies (i.e., medical insurance and pension schemes). However, the outmigration was also seen to impact the 
cultural identity of the village as the traditional peasant way of life might cease with the next generation.

Last but not least, in Wenhai, villagers were worried about plans for a new reservoir at Wenhai Lake. Livestock grazing, which was still the main livelihood activity, could be severely disturbed if the surrounding grasslands were flooded. Although compensation was promised and tourism was presumed to develop further, villagers were wary of such pledges. This in part derived from their previous experiences with government schemes as compensation was delayed or insufficient (e.g., tree planting and SLCP).

Climate change perception

The villagers in all three study sites had noticed a number of climatic changes especially during the past 10 years. Temperature was seen to have increased during both summer and winter. For instance, big icicles that used to form under the roof in winter were not seen anymore and bacon could not be stored as long as previously during winter time. Higher temperatures were also seen as the cause of greater prevalence of insect pests which had made pesticides indispensable. People not only felt the increasing temperatures in their own villages, but also in the city of Lijiang, where they felt that the summer heat made it difficult to breathe. The dwindling snow cover of the Jade Dragon Snow Mountain was regarded as the most visible indicator of rising temperatures. Villagers also mentioned earlier flowering of Rhododendron, which used to occur around the time of the Qingming festival (i.e., after $5^{\text {th }}$ April) and now occurs before the festival. Villagers had also observed changes in rainfall. The rainy season was reported to be delayed and a significant drop in precipitation was detected in July and August, resulting in the impression of 'no summer at all' by villagers. Decreasing rain was seen as the cause of declining numbers of mushrooms in the forest. 
Besides, villagers perceived an increasing variability in the climate, rendering it too volatile to predict. More sudden snows in March and unexpected frost at the flowering time of fruit trees were a few of the examples given by the villagers.

Despite similarities in the climatic trends reported by inhabitants of the three villages, the impacts were perceived quite differently. Villagers in Xihu (the lowest village) experienced mainly negative impacts since crops and fruit trees were adversely influenced. In particular, the erratic occurrence of frost and hailstorm had caused a lot of damage to peach flowers. In contrast, villagers in Wenhai (the highest village) experienced mainly positive impacts as increasing temperatures meant that more crops, such as peas and broad beans, could be grown at higher elevations. Increasingly drier conditions were also seen as more favourable for potato cultivation as it reduced the risk of the potatoes decaying in the field. Moreover, villagers deemed warmer climate more congenial to their health as they felt more comfortable. Also, warmer days meant that they could work more outside and needed less fuel wood. The villagers therefore recognised this favourable indirect effect of a warming climate on forest resources. In Wuzubi (at mid-elevation) villagers appeared quite indifferent to the observed climate changes. They did not regard climate change as a serious issue as the main crop (potatoes) was seen as quite drought-resistant, and the other crop, rapeseed, usually did well when potato did not.

\section{Climate change concerns}

Villagers generally expected that current trend of increasing temperature and decreasing precipitation would continue in the future. Additionally, intensified climate extremes were anticipated. For instance, more frequent drought was predicted to intrude upon the area in the next 2-3 years and hailstorms were conjectured to become more aberrant. 
Some livelihood activities were seen as being particularly susceptible to the envisaged climate trends. In Xihu and Wenhai this was first and foremost tourism due to the impact of climate change on natural resources. According to the villagers, the tourist attractions would completely disappear if the warming trend continued. The attractiveness of the villages would fade away as the lakes (i.e., Lashi Lake and Wenhai Lake) dried up and the ever-lasting snow of the Jade Dragon Snow Mountain melted. Besides, 'the sense of green' would dissipate when vegetables and fruit trees could no longer be grown under the drier climate. To make it worse, this process was believed to be aggravated by villagers themselves through environmentally destructive activities such as illegal logging, which could contribute further to the altering local landscape and climate, and increase the negative impacts of climate change. Although rangers were assigned in each village to guard the forests, according to the villagers, monitoring was not strictly enforced due to lack of commitment.

\section{Discussion}

Linking drivers of changes to adaptation

Over the past 30 years, households in all three villages have gone through livelihood transitions with several new strategies incorporated into their livelihood portfolios. While households typically maintain an assorted array of crop and livestock production, non-farm diversification is manifest in Xihu and Wenhai villages where engagement in tourism and temporary migrant work has been pronounced. In comparison, Wuzubi households have increasingly specialized within farming.

The active process of 'de-agrarianization' observed in Xihu and Wenhai village has rendered crop farming a rather residual activity, and livelihoods have become increasingly non-farm oriented. The drivers of this process are manifold. Firstly, farm size has decreased dramatically in both villages caused by farmland expropriation due to government initiatives. Secondly, small-scale farming is 
no longer profitable due to increased cost of investments caused by recent inflation and price fluctuations owing to market liberalization. Last but not least, tourism development, which is a top priority of the local government, has presented new profitable livelihood opportunities. Therefore, the 'de-agrarianization' process appears to be driven by a combination of government policies and economic trends. Likewise, the agricultural specialization in Wuzubi village is to a great extent triggered by economic considerations. The shift towards intensive cultivation of potatoes and rapeseed is facilitated by easy access to markets and high-yielding hybrid varieties of potatoes. Favourable market conditions have also contributed to the success of this specialty economy, driven by large demand for the product all over Yunnan province.

Although villagers have noticed the climate becoming warmer and drier, climate seems not to have played a major role in shaping livelihood changes over the past 30 years. One pertinent question is what implications decisions driven by non-climate forces have for climate change adaptation. The case study shows that some of the observed changes moderate climate change impacts, for instance the shift towards the more drought tolerant potato crop observed in Wuzubi. Likewise, certain policy interventions which are not concerned with climate change have had a positive influence and enabled household adaptation. Examples are investments in rural infrastructure construction, including roads, electricity/telecommunication and water facilities. Nowadays the villages have year-round road access and virtually each household possesses its own television. These infrastructure improvements have facilitated access to cities, markets and information thereby increasing the range of available livelihood options which is often seen as an important element of adaptation at the household level. Moreover, water facilities installed as part of the government's development agenda substantially relieved the drought stress placed upon people and crops in 2009/10. Studies from elsewhere in China and other parts of the world also document how 
adaptation to climate change has benefited from general rural development (Finan and Nelson 2001; Reid and Vogel 2006; Su et al. 2012; Tschakert 2007; Ziervogel et al. 2006). This leads us to two considerations. Firstly, non-climatic factors constitute the key context within which adaptation to climate change and hazards occurs, either exacerbating or counteracting the effects of climate upon livelihoods (Smit and Skinner 2002). Rural households are constantly confronted with 'double exposure', forcing them to adjust to socio-economic drivers of change, in particular markets, at the same time as climate change (Mertz et al. 2009; O'Brien and Leichenko 2000; Smit and Skinner 2002). The co-evolution of multiple forces has complicated the task of teasing out the impact of climate alone on changing livelihoods. This finding concurs well with results from other studies (Buchmann 2009; Hageback et al. 2005; Nielsen and Reenberg 2010; Reenberg et al. 2008). Secondly, the observed synergies between adaptation to climate change and development have given rise to the emerging process of 'mainstreaming' adaptation and integrating it with general development issues such as poverty reduction (Huq and Reid 2004). This study demonstrates that generic development and livelihood enhancement initiatives make sense as these actions can strengthen local people's capacity to respond to climate change impacts and reduce their vulnerability. The villages in this study are likely to benefit further from deliberative development planning if potential climate change impacts are taken into account.

However, not all developments are equally benign. For instance, the planned construction of the Wenhai Reservoir might challenge the traditional pastoralist life through its potential impact upon the surrounding pasture areas. Villagers have been promised compensation and it is hoped that the project will promote tourism development in the area. However, the benefits to villagers will depend on trends and developments within the tourism industry as well as on climate change impacts. Moreover, households differ in their ability to take advantage of new opportunities due to 
differences in their resources. For example, not everyone is able to take the risks entailed by horse riding business. Furthermore, people also differ in their inclinations and perceptions. Some pay more attention to potential positive effects while others do the opposite. These differences might lead to different livelihood adaptations, which deviate from the intended planning outcomes. This indicates that there is no perfectly planned path or panacea for adaptation. There is an urgent need for policy makers to be aware of the existence of divergent opinions and to focus particularly on those groups who doubt the planned developments. Further investigation of people's reluctance to adapt and change current practices may reveal key obstacles to their participation in such plans. These will need to be addressed if all households are to benefit equally.

\section{Linking adaptation to vulnerability}

Another related aspect is the outcome of livelihood changes on households' vulnerability. In general living standards have improved over the last 30 years (as witnessed by the shift in people's main concerns from basic necessities such as food to issues such as education). In some respects, adaptive capacity has also increased due to improvements in infrastructure and technology as well as increased annual incomes. Some of the changes in people's livelihoods have likewise contributed to reducing their sensitivity to climate change. For example, combining potato and rapeseed cultivation has functioned as a risk spreading mechanism and has reduced Wuzubi households' vulnerability to climatic fluctuations as the two crops have different climate sensitivities. This reduced farmers' total income loss during the severe drought in 2009/10 in stark contrast to previous drought impacts (before shifting to potatoes), such as when a drought in 1986/87 caused total crop failure. Nevertheless, some of the new livelihood activities such as fruit tree production and tourism remain sensitive to climate change. This is reflected in the different expectations across villages with regard to future impacts of climate change. So far, however, villagers' overall 
vulnerability seems to have decreased. This is despite increasing exposure to climate change as its impacts have been off-set by gains made through livelihood adaptations to the economic and political changes. This illustrates the importance of seeing vulnerability as the result of a dynamic process with linkages within the social-ecological systems, in which different and sometimes opposing factors interact in shaping overall vulnerability.

While the life of Xihu and Wuzubi villagers has improved substantially, Wenhai villagers are still struggling to search for better livelihood options. Vulnerability has thus been reduced to different degrees and it is highly important to acknowledge this heterogeneity in vulnerability across villages, which is linked to biophysical as well as socio-economic differences. For instance, although the villages are situated in close proximity, climatic conditions differ due to steep topography and elevation resulting in different opportunities with regard to which crops can be grown. More importantly, a number of socio-economic factors representing key components of social vulnerability differentiate the villages such as access to government extension services, NGO support and availability of technology and infrastructure. The lower elevation villages (Xihu and Wuzubi) have benefitted more from external assistance than the highland village (Wenhai). The uneven development within this small geographical area reflects a lack of vulnerability assessment of rural communities and corresponding prioritization when it comes to public investments and resource allocation. This should make local government bodies reconsider the criteria used to guide development and assistance so that the most vulnerable are given the needed attention, as in the case of Wenhai village which so far has been disadvantaged by both its location and policies.

A look into the future 
Households in this study have responded to past changes in multiple ways by diversifying their livelihoods or by intensifying agriculture. While the responses in general have reduced their vulnerability, this should not be regarded as a long term situation. Vulnerability is dynamic, and this study only presents a snap shot in time. Climate change will continue in the future and its impacts will develop as both biophysical and socio-economic circumstances continue to change. This was expressed by Xihu villagers, who were doubtful about the future viability of their livelihoods due to expected climate impacts on tourism and fruit tree plantations. The scenario in Xihu village suggests that diversified livelihoods do not necessarily move the households 'beyond climate' (Nielsen and Reenberg 2010) as non-farm activities such as tourism may still depend on natural resources (Ellis and Allison 2004) and therefore climate sensitive. Although it has been widely demonstrated that non-farm diversification can contribute to increased resilience and wellbeing by establishing flexible livelihood options and spreading risk (e.g., Cramb et al. 2009; Osbahr et al. 2008; Sallu et al. 2010; Su et al. 2012; Thornton et al. 2007), this study shows that this is not an automatic outcome but contingent upon the nature and mix of non-farm activities. Likewise, remaining within agriculture does not automatically entail high vulnerability as the example of Wuzubi shows.

Villagers' rising concern about climate change and natural resources seem to contradict some of their current livelihood practices such as illegal logging and charcoal making, which are perceived as having negative environmental and climatic impacts. Nevertheless, these activities are seen as an adaptation to the fluctuating nature of new livelihood activities (e.g., tourism). Adaptations and stressors are therefore entangled (McDowell and Hess 2012) within the social-ecological system through feedback mechanism, which could reinforce the stress from climate change on communities. 
The persistence of these activities even while villagers acknowledge their potential negative consequences may partly be due to the lack of alternative livelihood options, especially in Wenhai where access to markets and government services is limited. Another explanation may be found in the change of value system often associated with integration into the cash economy (Bullock 2003). This may promote a focus on short-term economic benefits from natural resource exploitation rather than on non-economic values assigned to the environment on the basis of traditional beliefs or religions. However, there seem to be large differences in the degree to which cultural values are being replaced by a focus on economic gains. A study amongst Tibetan communities in another part of Yunnan province showed that cultural and religious values ascribed to the natural landscape still played a strong role there (Byg and Salick 2009).

In Wuzubi village, another significant development is the migration of young people to urban areas. Nowadays most young people are well-educated and orient themselves towards the cities where life is seen as more comfortable. Although this is compatible with their parents' hope, this trend raises concerns for the future of farming and the village communities where agriculture is still predominant and lucrative. One important implication pertains to future agricultural productivity which might be undermined by loss of labor, farming skills and knowledge accompanying the migration trend. As this is the main potato cultivation area in Yunnan province, continuation of this development might compromise future supplies of potatoes. Thus, although migration might reduce vulnerability of individuals to climate change, the accumulated responses of individuals might lead to undesirable outcomes for communities and societies in the long run (Fazey et al. 2009), one of which could imply food insecurity. 
Recommendations for policy makers:

- Align policies targeting adaptation to climate change with generic development and livelihood enhancement initiatives to strengthen adaptive capacity of local communities;

- Be aware of the divergent responses to policies and pay particular attention to address potential barriers of engagement;

- Acknowledge the heterogeneity in households' vulnerability across locations and prioritize public investments and assistance to the ones most in need.

\section{Conclusions}

Considerable changes in livelihoods have taken place in Xihu, Wuzubi and Wenhai villages over the past 30 years. Households have been able to adopt a variety of strategies, including livelihood diversification, specialization and to some extent migration as a primary response to social and political influences. Even though villagers have also experienced climatic changes mainly in terms of increasing temperatures and decreasing precipitation, these have not necessarily functioned as the predominant driver of livelihood changes as such.

The observed changes have led to increasing affluence among villagers. Together with improved infrastructure and technology developments, this has led to increased adaptive capacity of communities. Consequently, overall vulnerability seems to have decreased despite increasing exposure to climate change on account of the gains obtained through adaptation to non-climate forces. Seen from this perspective, the paper draws attention to the emerging process of 'mainstreaming', where climate change adaptation is addressed concurrently with generic livelihood enhancement initiatives. 
Our observations emphasize the dynamic property of vulnerability. Some current livelihood practices (like fruit tree plantation and tourism) are natural resource based and climate sensitive. Other activities (such as illegal logging and charcoal making) are considered to contribute further to climate change in the long run through their adverse consequences on ecological systems. As such, vulnerability of communities might increase in the future considering increased exposure induced by climate change and the remaining susceptibility of presently pursued livelihoods. The paper therefore calls for specific attention to sustainable livelihood development, which emphasizes economic returns without introducing potential, negative ecological and climatic consequences.

\section{Acknowledgements}

The active participation of the Yi and Naxi communities and their generous hospitality are gratefully appreciated. We acknowledge the special support from Professor Yang Yongping, Professor Li Dezhu and Ms. Han Xi from Kunming Institute of Botany, Chinese Academy of Sciences. The local support from Lijiang Alpine Botanical garden is particularly acknowledged, especially the assistance from Dr. Wu Zhikun and Mr. Yang Yongning. The paper benefits from the work of local assistants, Ms. He Qiongji and Ms. Yang Lijuan. We are also grateful for the advice provided by Professor Anette Reenberg from Department of Geography and Geology, University of Copenhagen. We thank Mr. Gudina Legese Feyisa for making the map of the study area. We also appreciate the constructive comments provided by two anonymous reviewers. The research is partly funded by O.H.F \& A.J.-E Heilmanns Fond. Niels Strange and Bo Jellesmark Thorsen further acknowledge support from the Danish National Science Foundation. 


\section{References}

Adger, W. N. (2006). Vulnerability. Global Environmental Change 16(3): 268-281.

Bagchi, D. K., Blaikie, P., Cameron, J., Chattopadhyay, M., Gyawali, N. and Seddon, D. (1998). Conceptual and methodological challenges in the study of livelihood trajectories: Case studies in Eastern India and Western Nepal. Journal of International Development 10(4): 453-468.

Buchmann, C. (2009). Cuban home gardens and their role in social-ecological resilience. Human Ecology 37(6): 705-721.

Bullock, G. (2003). Creating positive synergies in mountain-based ecotourism development: Case studies from the Yunnan Great Rivers Project. In: Xu, J. and Mikesell, S. (eds.), Landscapes of Diversity: Indigenous Knowledge, Sustainable Livelihoods and Resource Governance in Montane Mainland Southeast Asia - Proceedings of the III Symposium on MMSEA 25-28 August 2012, Lijiang, PR China. Yunnan Science and Technology Press, Kunming, pp. 567-576.

Byg, A. and Salick, J. (2009). Local perspectives on a global phenomenon-climate change in Eastern Tibetan villages. Global Environmental Change 19(2): 156-166.

Coulthard, S. (2008). Adapting to environmental change in artisanal fisheries - Insights from a South Indian Lagoon. Global Environmental Change 18(3): 479-489.

Cramb, R. A., Colfer, C. J. P., Dressler, W., Laungaramsri, P., Le, Q. T., Mulyoutami, E., Peluso, N. L. and Wadley, R. L. (2009). Swidden transformations and rural livelihoods in Southeast Asia. Human Ecology 37(3): 323-346.

Davies, S. and Hossain, N. (1997). Livelihood adaptation, public action and civil society: A review of the literature, IDS Working Paper 57. Institute of Development Studies, Brighton.

De Haan, L. and Zoomers, A. (2005). Exploring the frontier of livelihoods research. Development and Change 36(1): 27-47.

Dearing, J. A., Braimoh, A. K., Reenberg, A., Turner, B. L. and van der Leeuw, S. (2010). Complex land systems: the need for long time perspectives to assess their future. Ecology and Society 15(4): 21.

Dercon, S. (2002). Income risk, coping strategies, and safety nets. World Bank Research Observer 17(2): 141-166.

Eakin, H. and Luers, A. L. (2006). Assessing the vulnerability of social-environmental systems. Annual review of Environment and Resources 31: 365-394.

Ellis, F. (1998). Household strategies and rural livelihood diversification. The Journal of Development Studies 35(1): 1-38.

Ellis, F. (2000a). The determinants of rural livelihood diversification in developing countries. Journal of Agricultural Economics 51(2): 289-302.

Ellis, F. (2000b). Rural livelihoods and diversity in developing countries. Oxford university press.

Ellis, F. and Allison, E. (2004). Livelihood diversification and natural resource access, Food and Agriculture Organization (FAO), Livelihood Support Program Working Paper (LSP WP) 9, Access to Natural Resources Sub-Programme, Livelihood Diversification and Enterprise Development. Overseas Development Group, University of Anglia, UK.

Ellis, F. and Biggs, S. (2001). Evolving themes in rural development 1950s - 2000s. Development Policy Review 19(4): 437-448.

Eriksen, S., Brown, K. and Kelly, P. M. (2005). The dynamics of vulnerability: Locating coping strategies in Kenya and Tanzania. The Geographical Journal 171(4): 287-305. 
Fazey, I., Gamarra, J. G. P., Fischer, J., Reed, M. S., Stringer, L. C. and Christie, M. (2009). Adaptation strategies for reducing vulnerability to future environmental change. Frontiers in Ecology and the Environment 8(8): 414-422.

Finan, T. J. and Nelson, D. R. (2001). Making rain, making roads, making do: Public and private adaptations to drought in Ceará, Northeast Brazil. Climate Research 19(2): 97-108.

Hageback, J., Sundberg, J., Ostwald, M., Chen, D., Yun, X. and Knutsson, P. (2005). Climate variability and land-use change in Danangou Watershed, China-Examples of small-scale farmers' adaptation. Climatic Change 72(1): 189-212.

Hershkovitz, L. (1993). Political ecology and environmental management in the Loess Plateau, China. Human Ecology 21(4): 327-353.

Huq, S. and Reid, H. (2004). Mainstreaming adaptation in development. IDS Bulletin 35(3): 15-21.

IPCC. (2001). Technical summary: Climate change 2001: Impacts, adaptation, and vulnerability. A report of Working Group II of the Intergovernmental Panel on Climate Change, Geneva. http://www.grida.no/climate/ipcc tar/wg2/pdf/wg2TARtechsum.pdf.

Liu, C., Golding, D. and Gong, G. (2008). Farmers' coping response to the low flows in the lower Yellow River: A case study of temporal dimensions of vulnerability. Global Environmental Change 18(4): 543-553.

Malchow-Møller, N. and Thorsen, B. J. (2005). The buffer-stock consumption model with endogenous income shifts. The BE Journal of Macroeconomics 5(1): 1-27.

McDowell, J. Z. and Hess, J. J. (2012). Accessing adaptation: Multiple stressors on livelihoods in the Bolivian highlands under a changing climate. Global Environmental Change 22(2): 342352.

Mertz, O., Halsnæs, K., Olesen, J. E. and Rasmussen, K. (2009). Adaptation to climate change in developing countries. Environmental Management 43(5): 743-752.

Nielsen, J. O. and Reenberg, A. (2010). Temporality and the problem with singling out climate as a current driver of change in a small West African village. Journal of Arid Environments 74(4): 464-474.

Ning, B., He, Y., He, X., Pang, H., Yuan, L., Zhao, J., Lu, A. and Song, B. (2006). Potential impacts of glacier retreating of the Mt. Yulong on the socioeconomic development in Lijiang City. Journal of Glaciology and Geocryology 28(6): 885-892.

O'Brien, K. L. and Leichenko, R. M. (2000). Double exposure: assessing the impacts of climate change within the context of economic globalization. Global Environmental Change 10(3): 221-232.

Osbahr, H., Twyman, C., Adger, W. N. and Thomas, D. S. G. (2008). Effective livelihood adaptation to climate change disturbance: Scale dimensions of practice in Mozambique. Geoforum 39(6): 1951-1964.

Paavola, J. (2008). Livelihoods, vulnerability and adaptation to climate change in Morogoro, Tanzania. Environmental Science \& Policy 11(7): 642-654.

Porro, R. (2005). Palms, pastures, and swidden fields: The grounded political ecology of "agroextractive/shifting-cultivator peasants" in Maranhao, Brazil. Human Ecology 33(1): 17-56.

Reenberg, A. (2011). Toolbox options for conceptualizing change in human-environmental systems - Pathways, path dependency, legacies, syndromes and scenarios, GLP Report No 2 Global Land Project.

Reenberg, A., Birch-Thomsen, T., Mertz, O., Fog, B. and Christiansen, S. (2008). Adaptation of human coping strategies in a small island society in the SW pacific - 50 years of change in the coupled human-environment system on Bellona, Solomon Islands. Human Ecology 36(6): 807-819. 
Reid, P. and Vogel, C. (2006). Living and responding to multiple stressors in South Africa Glimpses from KwaZulu-Natal. Global Environmental Change 16(2): 195-206.

Sallu, S. M., Twyman, C. and Stringer, L. C. (2010). Resilient or vulnerable Livelihoods? Assessing livelihood dynamics and trajectories in rural Botswana. Ecology and Society 15(4): 3 .

Scoones, I. (1998). Sustainable rural livelihoods: A framework for analysis, IDS Working Paper 72. Institute of Development Studies, Brighton.

Sicroff, S., Alos, E. and Shrestha, R. (2003). Independent backpacker tourism: Key to sustainable development in remote mountain destinations. In: Xu, J. and Mikesell, S. (eds.), Landscapes of Diversity: Indigenous Knowledge, Sustainable Livelihoods and Resource Governance in Montane Mainland Southeast Asia - Proceedings of the III Symposium on MMSEA 25-28 August 2002, Lijiang, PR China. Yunnan Science and Technology Press, Kunming, pp. 527-543.

Smit, B. and Skinner, M. W. (2002). Adaptation options in agriculture to climate change: A typology. Mitigation and Adaptation Strategies for Global Change 7(1): 85-114.

Smit, B. and Wandel, J. (2006). Adaptation, adaptive capacity and vulnerability. Global Environmental Change 16(3): 282-292.

Su, Y., Xu, J., Wilkes, A., Lu, J., Li, Q., Fu, Y., Ma, X. and Grumbine, R. E. (2012). Coping with climate-induced water stresses through time and space in the mountains of Southwest China. Regional Environmental Change 12(4): 855-866.

Thornton, P. K., Boone, R. B., Galvin, K. A., BurnSilver, S. B., Waithaka, M. M., Kuyiah, J., Karanja, S., González-Estrada, E. and Herrero, M. (2007). Coping strategies in livestockdependent households in East and southern Africa: A synthesis of four case studies. Human Ecology 35(4): 461-476.

Tilt, B. (2008). Smallholders and the 'household responsibility system': Adapting to institutional change in Chinese agriculture. Human Ecology 36(2): 189-199.

Tschakert, P. (2007). Views from the vulnerable: Understanding climatic and other stressors in the Sahel. Global Environmental Change 17(3-4): 381-396.

Turner, B. L., Kasperson, R. E., Matson, P. A., McCarthy, J. J., Corell, R. W., Christensen, L., Eckley, N., Kasperson, J. X., Luers, A. and Martello, M. L. (2003). A framework for vulnerability analysis in sustainability science. Proceedings of the National Academy of Sciences 100(14): 8074-8079.

Yuan, L. L., Lu, A. G., Ning, B. Y. and He, Y. Q. (2006). Impacts of Yulong Mountain glacier on tourism in Lijiang. Journal of Mountain Science 3(1): 71-80.

Zackey, J. (2007). Peasant perspectives on deforestation in southwest China. Mountain Research and Development 27(2): 153-161.

Zhao, Y. (1999). Labor migration and earnings differences: The case of rural China. Economic Development and Cultural Change 47(4): 767-782.

Ziervogel, G., Bharwani, S. and Downing, T. E. (2006). Adapting to climate variability: Pumpkins, people and policy. Natural Resources Forum 30(4): 294-305. 